Prepared in cooperation with the Indiana Office of Community and Rural Affairs

\title{
Flood-Inundation Maps for the White River at Indianapolis, Indiana, 2014
}

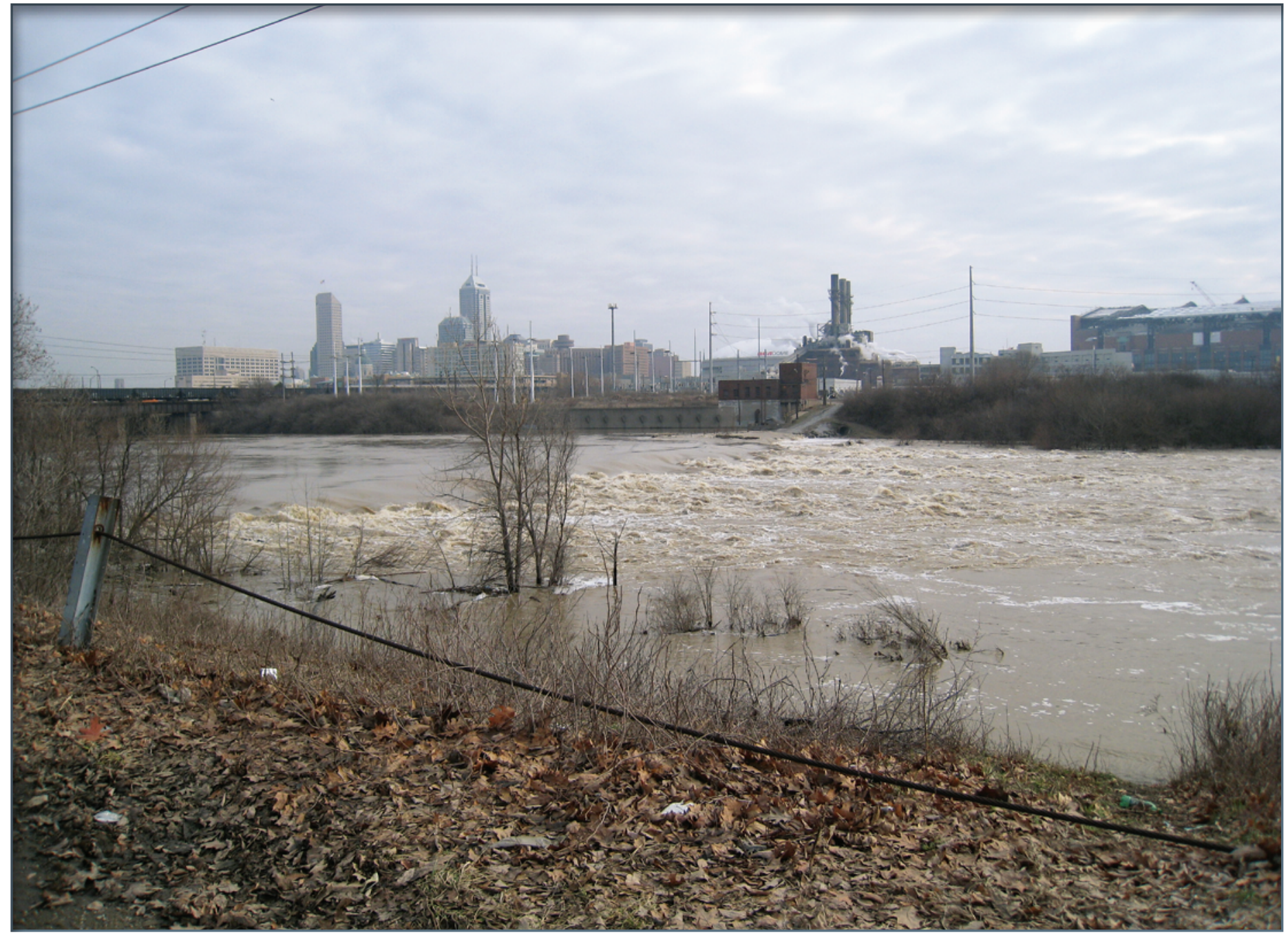

Scientific Investigations Report 2015-5051 
Cover. Photograph taken by U.S. Geological Survey hydrologic technician Ron Knapp during a flood measurement made on the White River at Indianapolis, Indiana, February 2008. 


\title{
Flood-Inundation Maps for the White River at Indianapolis, Indiana, 2014
}

\author{
By Elizabeth A. Nystrom
}

Prepared in cooperation with the Indiana Office of Community and Rural Affairs

Scientific Investigations Report 2015-5051 


\title{
U.S. Department of the Interior SALLY JEWELL, Secretary
}

\section{U.S. Geological Survey \\ Suzette M. Kimball, Acting Director}

\author{
U.S. Geological Survey, Reston, Virginia: 2015
}

For more information on the USGS - the Federal source for science about the Earth, its natural and living resources, natural hazards, and the environment—visit http://www.usgs.gov or call 1-888-ASK-USGS.

For an overview of USGS information products, including maps, imagery, and publications, visit http://www.usgs.gov/ pubprod/.

Any use of trade, firm, or product names is for descriptive purposes only and does not imply endorsement by the U.S. Government.

Although this information product, for the most part, is in the public domain, it also may contain copyrighted materials as noted in the text. Permission to reproduce copyrighted items must be secured from the copyright owner.

Suggested citation:

Nystrom, E.A., 2015, Flood-inundation maps for the White River at Indianapolis, Indiana, 2014: U.S. Geological Survey Scientific Investigations Report 2015-5051, 12 p., http://dx.doi.org/10.3133/sir20155051.

ISSN 2328-0328 (online) 


\section{Contents}

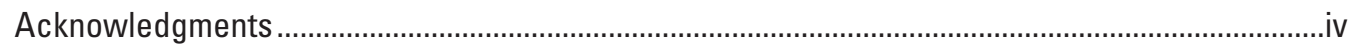

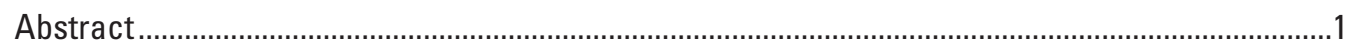

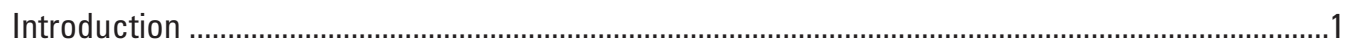

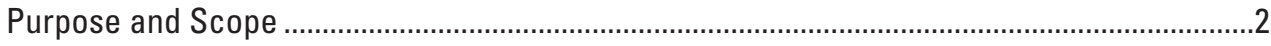

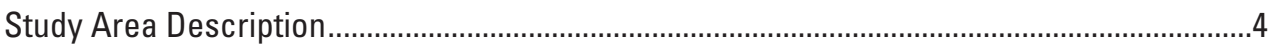

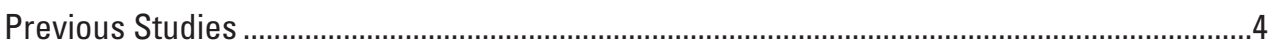

Creation of Flood-Inundation-Map Library .......................................................................................

Computation of Water-Surface Profiles.....................................................................................5

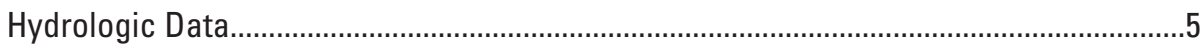

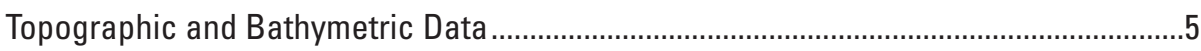

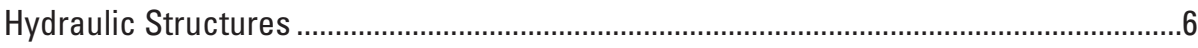

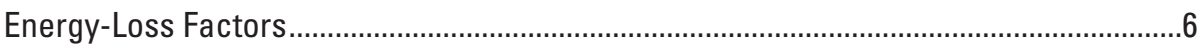

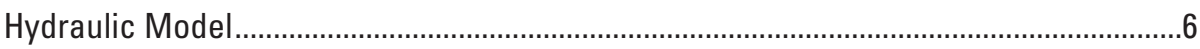

Development of Water-Surface Profiles...........................................................................8

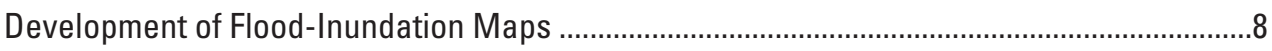

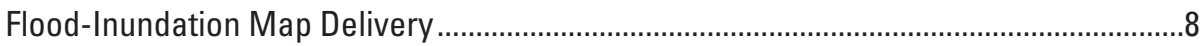

Disclaimer for Flood-Inundation Maps ..............................................................................10

Uncertainties and Limitations Regarding Use of Flood-Inundation Maps .....................10

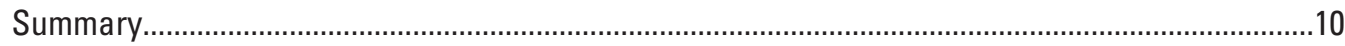

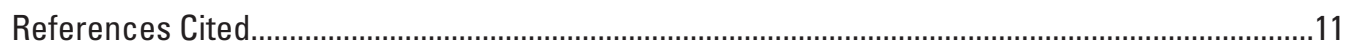

\section{Figures}

1. Map showing location of the study reach for the White River at Indianapolis, Indiana, and location of U.S. Geological Survey (USGS) streamgages along the study reach..........3

2. Flood-inundation map for the White River at Indianapolis, Indiana, corresponding to a stage of 20.00 feet at the USGS streamgage (station number 03353000 )

\section{Tables}

1. Information for U.S. Geological Survey streamgages along the study reach, White River, Indianapolis, Indiana .....

2. Peak discharges for selected annual exceedance probabilities for White River at Indianapolis, Indiana

3. Estimated discharges for corresponding stages and water-surface elevations at selected locations, used in the hydraulic model of the White River at Indianapolis, Indiana

4. Calibration of model to target water-surface elevations at U.S. Geological Survey streamgage on White River at Michigan Street at Indianapolis, Indiana.

5. Calibration of model to target water-surface elevations at U.S. Geological Survey streamgage on White River at Indianapolis, Indiana (station number 03353000).............7

6. Calibration of model to target water-surface elevations at U.S. Geological Survey streamgage on White River at Stout Generating Station at Indianapolis, Indiana. 


\section{Conversion Factors}

Inch/Pound to International System of Units

\begin{tabular}{lll}
\hline \multicolumn{1}{c}{ Multiply } & By & \multicolumn{1}{c}{ To obtain } \\
\hline & Length & \\
\hline inch (in.) & 2.54 & centimeter $(\mathrm{cm})$ \\
foot (ft) & 0.3048 & meter $(\mathrm{m})$ \\
mile (mi) & 1.609 & kilometer $(\mathrm{km})$ \\
\hline & Area & \\
\hline square mile $\left(\mathrm{mi}^{2}\right)$ & 2.590 & square kilometer $\left(\mathrm{km}^{2}\right)$ \\
\hline & Flow rate & \\
\hline cubic foot per second $\left(\mathrm{ft}^{3} / \mathrm{s}\right)$ & 0.02832 & cubic meter per second $\left(\mathrm{m}^{3} / \mathrm{s}\right)$ \\
\hline
\end{tabular}

\section{Datums}

Vertical coordinate information is referenced to (1) stage, the height above an arbitrary datum established at a streamgage; and (2) elevation, the height above the North American Vertical Datum of 1988 (NAVD 88).

Horizontal coordinate information is referenced to the North American Datum of 1983 (NAD 83).

Elevation, as used in this report, is the distance above the vertical datum.

\section{Acknowledgments}

The author wishes to thank the agencies that have cooperated in the funding for the operation and maintenance of the streamgages used for this study, including the Indiana Office of Community and Rural Affairs, the Indiana Department of Natural Resources, the city of Indianapolis, the Ohio River Valley Water Sanitation Commission, and Indiana University-Purdue University Indianapolis (IUPUI). Tracey Humphrey from the Indianapolis Department of Public Works and Ron Raney and Janie Marks from the Indiana Department of Transportation provided bridge and levee data. Special thanks are given to the National Weather Service for their continued support of the U.S. Geological Survey flood-inundation mapping program. 


\title{
Flood-Inundation Maps for the White River at Indianapolis, Indiana, 2014
}

\author{
By Elizabeth A. Nystrom
}

\section{Abstract}

Digital flood-inundation maps for a 6.4-mile reach of the White River in Indianapolis, Indiana, from 0.3 miles upstream of Michigan Street to the Harding Street Generating Station dam (at the confluence with Lick Creek), were created by the U.S. Geological Survey (USGS) in cooperation with the Indiana Office of Community and Rural Affairs. The flood-inundation maps, which can be accessed through the USGS Flood Inundation Mapping Science Web site at http://water.usgs.gov/ osw/flood_inundation/, depict estimates of the areal extent and depth of flooding corresponding to selected water levels (stages) at the USGS streamgage on the White River at Indianapolis, Ind. (station number 03353000). Near-real-time stages at this streamgage may be obtained on the Internet from the USGS National Water Information System at http://waterdata. usgs.gov/ or the National Weather Service (NWS) Advanced Hydrologic Prediction Service at http://water.weather.gov/ ahps/, which also forecasts flood hydrographs at this site.

Flood profiles were computed for the stream reach by means of a one-dimensional step-backwater model. The model was calibrated by using the current stage-discharge relations at three USGS streamgages: the White River at Indianapolis (station number 03353000), the White River at Michigan Street at Indianapolis (station number 03352953), and the White River at Stout Generating Station at Indianapolis (station number 03353611).

The hydraulic model was then used to compute 11 watersurface profiles for flood stages at 1-foot (ft) intervals referenced to the White River at Indianapolis streamgage datum and ranging from $10 \mathrm{ft}$, or the NWS “action stage," to $20 \mathrm{ft}$, which is the highest stage in the stage-discharge relation for the streamgage and the NWS "moderate flood stage."

The simulated water-surface profiles were then combined with a geographic information system digital elevation model (derived from light detection and ranging [lidar] data having a vertical $0.183-\mathrm{ft}$ root mean squared error and 5.0-ft horizontal resolution) to delineate the area flooded at each water level.

The availability of these maps, along with Internet information regarding current stage from the USGS streamgage and forecasted high-flow stages from the NWS, will provide emergency management personnel and residents with information that is critical for flood response activities such as evacuations and road closures, as well as for postflood recovery efforts.

\section{Introduction}

The city of Indianapolis, in Marion County, Indiana (Ind.), is a large urban community, with a population of 820,445 in 2010 (U.S. Census Bureau, 2010), and is the State capital and the seat of Marion County. The White River flows through Indianapolis from north to south, passing to the west of downtown; several U.S. Geological Survey (USGS) streamgages are located within the city limits. A large portion of the city of Indianapolis (18 percent) is considered to be part of a flood plain (City of Indianapolis, 2014); Indianapolis has experienced flooding from the White River and its tributaries numerous times, most significantly in 1913 and more recently in 2003, 2005, and 2013. The flood of 1913 inundated 6 square miles $\left(\mathrm{mi}^{2}\right)$ in Indianapolis, destroyed bridges and levees, damaged or destroyed 4,000 homes, and killed at least 5 people (Silver Jackets, 2013) with more damage statewide. In September 2003, more than 7 inches of rain fell in Indianapolis, causing the White River to rise 15 feet (ft) in 18 hours; the National Guard was activated to assist in emergency response (National Weather Service, 2009).

Prior to this study, emergency responders in Indianapolis relied on several information sources (all of which are available on the Internet) to make decisions on how to best alert the public and mitigate flood damages. One source is the Federal Emergency Management Agency (FEMA) flood insurance study (FIS) for Marion County, Ind., dated July 5, 2005 (Federal Emergency Management Agency, 2005). An updated, preliminary (as of 2014) version of the FIS (Federal Emergency Management Agency, 2014) also is available. A second source of information is the USGS streamgage 03353000, White River at Indianapolis, Ind., from which current (U.S. Geological Survey, 2014a) and historical (with more than 85 years of daily discharge data and more than 100 years of peak streamflow data since 1904; U.S. Geological Survey, 2014b) water levels and discharges, including annual peak flows, can be obtained. A third source of flood-related information is the National Weather Service (NWS) Advanced Hydrologic Prediction Service (AHPS), which displays the USGS stage data, and issues forecasts of stage for the White River at Indianapolis (NWS station White River at Raymond Street in Indianapolis, INDI3), (National Weather Service, 2014a). The NWS issues forecasts for the White River at Indianapolis routinely year-round. 
Although the current stage at a USGS streamgage is particularly useful for residents in the immediate vicinity of a streamgage, it is of limited use to residents farther upstream or downstream because the water-surface elevation is not constant along the entire stream reach. Knowledge of a water level at a streamgage is difficult to translate into depth and areal extent of flooding at points distant from the streamgage. One way to address these informational gaps is to produce a library of flood-inundation maps that are referenced to the stages recorded at the USGS streamgage. By referring to the appropriate map, emergency responders can discern the severity of flooding (depth of water and areal extent), identify roads that are or will soon be flooded, and make plans for notification or evacuation of residents in harm's way for some distance upstream and downstream from the streamgage. In addition, the capability to visualize the potential extent of flooding has been shown to motivate residents to take precautions and heed warnings that they previously might have disregarded. In 2012-14, the USGS, in cooperation with the Indiana Office of Community and Rural Affairs, conducted a project to produce a library of flood-inundation maps for the White River at Indianapolis, Ind.

\section{Purpose and Scope}

This report describes the development of a series of estimated flood-inundation maps for the White River at Indianapolis, Ind., and identifies where on the Internet the maps can be found and ancillary data (geographic information system [GIS] flood polygons and depth grids) can be downloaded. The flood-inundation maps cover a 6.4-mile (mi) reach of the White River in central Indianapolis, from 0.3 mi upstream of the Michigan Street bridge (and $0.1 \mathrm{mi}$ downstream of the confluence with Fall Creek) to the Harding Street Generating Station dam, at the confluence with Lick Creek (fig. 1). The maps were produced for flood levels referenced to the stage recorded at the USGS streamgage 03353000 on the White River at Indianapolis (table 1), which is located approximately midway through the study reach. The maps cover a range in stage from 10 to $20 \mathrm{ft}$, gage datum. The $10-\mathrm{ft}$ stage is approximately bankfull and is defined by the NWS (2014b) as the "action stage" or that stage which, when reached by a rising stream, requires the NWS or a partner to take some type of mitigation action in preparation for possible significant hydrologic activity. The 20 -ft stage is the highest stage in the stagedischarge relation for the streamgage and the NWS "moderate flood stage." This stage also exceeds that of the highest stage recorded at the streamgage's current (since 2000) site and datum, that of $19.65 \mathrm{ft}$, which occurred on September 1, 2003.

Two additional USGS streamgages are present in the study reach (table 1), 03352953, White River at Michigan Street at Indianapolis, Ind. (3.1 mi upstream from the reference streamgage) and 03353611, White River at Stout Generating Station at Indianapolis, Ind. (2.6 mi downstream of the reference streamgage); stage-discharge relations from these streamgages were used in calibration of the hydraulic model, but the inundation maps are not referenced to these streamgages. The NWS does not forecast stages at these sites.

Table 1. Information for U.S. Geological Survey streamgages along the study reach, White River, Indianapolis, Indiana.

[Station locations are shown in figure 1; DA, drainage area; $\mathrm{mi}^{2}$, square miles; $\mathrm{ft}$, feet; $\mathrm{ft}^{3} / \mathrm{s}$, cubic feet per second]

\begin{tabular}{|c|c|c|c|c|c|c|c|}
\hline Station name & $\begin{array}{l}\text { Station } \\
\text { number }\end{array}$ & $\begin{array}{c}\mathrm{DA} \\
\left(\mathrm{mi}^{2}\right)\end{array}$ & Latitude & Longitude & $\begin{array}{l}\text { Period of } \\
\text { peak-flow } \\
\text { record }\end{array}$ & $\begin{array}{c}\text { Maximum } \\
\text { recorded } \\
\text { stage (ft) and } \\
\text { date }\end{array}$ & $\begin{array}{c}\text { Maximum } \\
\text { discharge }\left(\mathrm{ft}^{3} / \mathrm{s}\right) \\
\text { and date }\end{array}$ \\
\hline $\begin{array}{l}\text { White River at Michigan Street } \\
\text { at Indianapolis }\end{array}$ & 03352953 & 1,622 & $39^{\circ} 46^{\prime} 29^{\prime \prime}$ & $86^{\circ} 11^{\prime} 23^{\prime \prime}$ & $\begin{array}{l}2005 \text { to current } \\
\text { year }(2014)\end{array}$ & $\begin{array}{l}\text { 17.48, } \\
\quad \text { Jan. } 6,2005\end{array}$ & $\begin{array}{l}37,000, \\
\quad \text { Jan. } 6,2005\end{array}$ \\
\hline White River at Indianapolis & 03353000 & 1,635 & $39^{\circ} 44^{\prime} 14^{\prime \prime}$ & $86^{\circ} 10^{\prime} 08^{\prime \prime}$ & $\begin{array}{l}1904 \text { to } 1906 \\
\text { and } 1912 \text { to } \\
\text { current year } \\
\text { (2014) }\end{array}$ & $\begin{array}{l}{ }^{130.0}, \\
\quad \text { Mar. 26, } 1913\end{array}$ & $\begin{array}{l}270,000, \\
\quad \text { Mar. 26, } 1913\end{array}$ \\
\hline $\begin{array}{l}\text { White River at Stout Generating } \\
\text { Station at Indianapolis }\end{array}$ & 03353611 & 1,898 & $39^{\circ} 42^{\prime} 52^{\prime \prime}$ & $86^{\circ} 12^{\prime} 02^{\prime \prime}$ & $\begin{array}{l}1992 \text { to current } \\
\text { year (2014) }\end{array}$ & $\begin{array}{l}\text { 15.42, } \\
\quad \text { Sept. } 1,2003\end{array}$ & $\begin{array}{l}51,500, \\
\text { Sept. } 1,2003\end{array}$ \\
\hline
\end{tabular}

\footnotetext{
${ }^{1}$ Stage recorded at different site and datum than current streamgage. Peak stage at current streamgage location $19.65 \mathrm{ft}$, Sept. 1, 2003; corresponding discharge $42,500 \mathrm{ft}^{3} / \mathrm{s}$.

${ }^{2}$ Estimated value.
} 
$86^{\circ} 13^{\prime}$

$86^{\circ} 11^{\prime}$

$86^{\circ} 9^{\prime}$

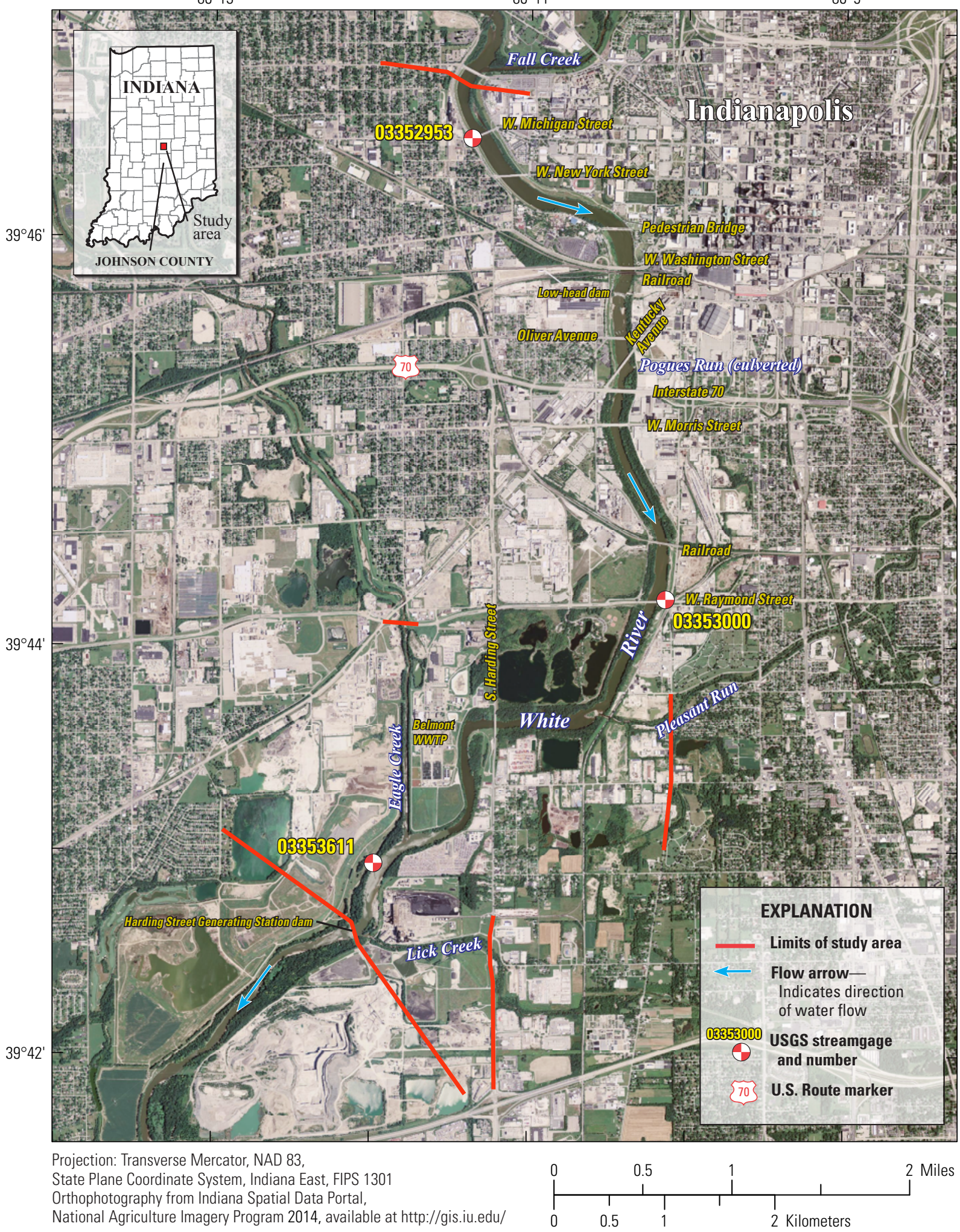

Figure 1. Location of the study reach for the White River at Indianapolis, Indiana, and location of U.S. Geological Survey (USGS) streamgages along the study reach. 
Flood-Inundation Maps for the White River at Indianapolis, Indiana, 2014

\section{Study Area Description}

The White River originates in Randolf County, and flows from northeast to southwest in central and southern Indiana to join the Wabash River. The study reach is approximately $6.4 \mathrm{mi}$ long, has an average channel width of $340 \mathrm{ft}$, and is located in Indianapolis, Marion County, in central Indiana. Land use within the study reach is predominantly urban and industrial, with open and park space immediately adjacent to the main channel through much of the reach, especially the northern part of the study reach.

Several tributaries join the White River within the study reach, including Pogues Run, Pleasant Run, Eagle Creek, and Lick Creek; the drainage area increases approximately 18 percent through the study reach from 1,610 to $1,898 \mathrm{mi}^{2}$. The drainage area of the White River at Indianapolis streamgage 03353000 is $1,635 \mathrm{mi}^{2}$. Fall Creek joins the White River just upstream of the study reach, and the City of Indianapolis Belmont Advanced Wastewater Treatment Facility outfall is located just upstream of the Eagle Creek confluence. Three major reservoirs are located upstream of the study reach, including Eagle Creek Reservoir, Geist Reservoir (located on Fall Creek), and Morse Reservoir (located on Cicero Creek, a tributary of White River, north of Indianapolis). Eagle Creek Reservoir is used primarily as a flood-control reservoir and secondarily for drinking water supply (Federal Emergency Management Agency, 2005; Citizens Energy Group, 2014), whereas Geist and Morse Reservoirs are used primarily for drinking water supply (Citizens Energy Group, 2014). High flows and regulated releases in Eagle Creek can cause backwater in the White River (U.S. Geological Survey, 2013); additionally, high flows in the White River can cause backwater in its tributaries, especially in areas along Lick Creek (National Weather Service, 2014a). Variable backwater generated by and along tributaries is not considered in this study.

The study reach is traversed by 12 bridges, including 2 railroad bridges, 1 pedestrian bridge (the former West Washington Street), and 9 roadways, including Interstate 70. Two broad-crested concrete and rock low-head dams are present in the study reach. Levees are present along much of the study reach, some of which are included in the National Levee Database (U.S. Army Corps of Engineers, 2014). Many levees in the study reach are maintained by the city of Indianapolis.

\section{Previous Studies}

The current FIS for Marion County (Federal Emergency Management Agency, 2005) is based on hydrologic and hydraulic analyses completed by the U.S. Army Corps of Engineers, Louisville District, in August 1979. The FIS presents estimates of the peak discharges with 10,2, 1, and 0.2 percent annual exceedance probabilities (table 2) and their associated water-surface elevations for the White River at the Marion/ Johnson county line.

A pilot flood-inundation mapping study for an 11-mi reach of the White River in Indianapolis, approximately $3.8 \mathrm{mi}$ upstream of the study reach described in this report, was coordinated by the Indiana Silver Jackets hazard mitigation taskforce (Kim and others, 2011). The pilot study was conducted by the U.S. Geological Survey, the NWS, the Polis Center of Indiana University-Purdue University Indianapolis, and Indiana University, in cooperation with the city of Indianapolis, the Indianapolis Museum of Art, the Indiana Department of Homeland Security, and the Indiana Department of Natural Resources-Division of Water; it used a two-dimensional hydraulic model to produce a library of static inundation maps for an 11-mi reach of the White River.

\section{Creation of Flood-Inundation-Map Library}

The USGS has standardized the procedures for creating flood-inundation maps for flood-prone communities (U.S. Geological Survey, 2014c) so that the process followed and products produced are similar regardless of which USGS office is responsible for the work. Tasks specific to development of the flood maps for Indianapolis, Ind., were (1) compilation of streamflow data from streamgages 03352953,03353000 , and 03353611 ; (2) collection of bathymetric data for selected cross sections and geometric data for structures and bridges along the study reach; (3) estimation of energy-loss factors (roughness coefficients) in the stream channel and flood plain and determination of steady-flow data; (4) computation of water-surface profiles using the U.S. Army Corps of Engineers' HEC-RAS computer program (U.S. Army Corps of Engineers, 2010); (5) production of

Table 2. Peak discharges for selected annual exceedance probabilities for White River at Indianapolis, Indiana.

$\left[\mathrm{mi}^{2}\right.$, square miles; $\mathrm{ft}^{3} / \mathrm{s}$, cubic feet per second; data from Federal Emergency Management Agency, 2005]

\begin{tabular}{lcccc}
\hline \multirow{2}{*}{ Location on White River } & Drainage & \multicolumn{4}{c}{ Estimated discharges $\left(\mathrm{ft}^{3}\right.$ /s) for indicated annual exceedance probabilities, in percent } \\
\cline { 3 - 5 } & area $\left(\mathbf{m i}^{2}\right)$ & $\mathbf{1 0}$ & $\mathbf{2}$ & $\mathbf{1}$ \\
\hline Marion/Johnson county line & 1,950 & 38,000 & 54,000 & 62,000 \\
\hline
\end{tabular}


estimated flood-inundation maps at various stream stages using the U.S. Army Corps of Engineers' HEC-GeoRAS computer program (U.S. Army Corps of Engineers, 2009) and a GIS; and (6) preparation of the maps, both as shapefile polygons that depict the areal extent of flood inundation and as depth grids that provide the depth of floodwaters, for display on a USGS flood-inundation mapping application.

\section{Computation of Water-Surface Profiles}

The water-surface profiles used to produce the 11 floodinundation maps in this study were computed by using HECRAS, version 4.1.0 (U.S. Army Corps of Engineers, 2010). HEC-RAS is a one-dimensional step-backwater model for simulation of water-surface profiles with steady-state (gradually varied) or unsteady-state flow computation options.

\section{Hydrologic Data}

The study reach includes three streamgages (fig. 1; table 1), all of which were already in operation at the start of this study. Stage is measured every 15 minutes, transmitted hourly by a satellite radio in the streamgage, and made available on the Internet through the USGS National Water Information System (NWIS; U.S. Geological Survey, 2014b). Stage data from these streamgages are referenced to a local datum but can be converted to water-surface elevations referenced to the North American Vertical Datum of 1988 (NAVD 88) by adding an offset; $669.56 \mathrm{ft}$ at streamgage 03352953 , $661.76 \mathrm{ft}$ at streamgage 03353000 , and $662.96 \mathrm{ft}$ at streamgage 03353611. Continuous records of streamflow are computed from stage-discharge relations, which have been developed for the streamgages, and are available through the USGS NWIS Web site.

The peak flows used in the model simulations (table 3) were taken from the current stage-discharge relation for streamgage 03353000 (number 52.0, effective September 1, 2003) and corresponded with the target stages. Four tributaries_-Pogues Run, Pleasant Run, Eagle Creek, and Lick Creek - join the White River within the 6.4-mi study reach; the streamgage-derived discharges were adjusted to account for tributary inflows (table 3 ). These adjustments were estimated by applying a drainage-area ratio to the main-channel flows.

\section{Topographic and Bathymetric Data}

All topographic data used in this study are referenced vertically to NAVD 88 and horizontally to the North American Datum of 1983 (NAD 83). Cross-section elevation data were obtained from a digital elevation model (DEM) that was derived from light detection and ranging (lidar) data that were collected during December 2009, by Indianapolis Metropolitan Planning Organization (IndyMPO), Indianapolis Mapping and Geographic Infrastructure System (IMAGIS) (Greater Indianapolis Area Aerial Lidar Survey, 2010) and subsequently

Table 3. Estimated discharges for corresponding stages and water-surface elevations at selected locations, used in the hydraulic model of the White River at Indianapolis, Indiana.

[ft, feet; NAVD 88, North American Vertical Datum of 1988]

\begin{tabular}{|c|c|c|c|c|c|c|}
\hline \multirow[b]{2}{*}{$\begin{array}{c}\text { Stage of } \\
\text { water-surface } \\
\text { profile (ft) }\end{array}$} & \multirow[b]{2}{*}{$\begin{array}{c}\text { Water-surface } \\
\text { elevation } \\
\text { (ft, NAVD 88) }\end{array}$} & \multicolumn{5}{|c|}{ Estimated discharge at indicated location, in cubic feet per second } \\
\hline & & $\begin{array}{l}\text { At upstream } \\
\text { end of study } \\
\text { reach }\end{array}$ & $\begin{array}{c}\text { Downstream from } \\
\text { confluence with } \\
\text { Pogues Run }\end{array}$ & $\begin{array}{c}\text { Downstream from } \\
\text { confluence with } \\
\text { Pleasant Run }\end{array}$ & $\begin{array}{c}\text { Downstream from } \\
\text { confluence with } \\
\text { Eagle Creek }\end{array}$ & $\begin{array}{c}\text { Downstream from } \\
\text { confluence with } \\
\text { Lick Creek }\end{array}$ \\
\hline 10 & 671.76 & 10,168 & 10,300 & 10,445 & 11,798 & 11,950 \\
\hline 11 & 672.76 & 12,537 & 12,700 & 12,879 & 14,548 & 14,734 \\
\hline 12 & 673.76 & 15,104 & 15,300 & 15,515 & 17,526 & 17,750 \\
\hline 14 & 675.76 & 20,928 & 21,200 & 21,498 & 24,284 & 24,595 \\
\hline 15 & 676.76 & 24,087 & 24,400 & 24,743 & 27,950 & 28,308 \\
\hline 16 & 677.76 & 27,542 & 27,900 & 28,292 & 31,959 & 32,368 \\
\hline 17 & 678.76 & 31,194 & 31,600 & 32,044 & 36,197 & 36,661 \\
\hline
\end{tabular}

\footnotetext{
${ }^{1}$ Water-surface profiles are 1-ft increments of stage, referenced to the gage datum of the U.S. Geological Survey streamgage, White River at Indianapolis,
} Indiana (station number 03353000). 
incorporated into a 2011 Statewide lidar dataset by Woolpert, Inc. (2011). The lidar data have horizontal resolution of $5.0 \mathrm{ft}$ (1.5 meters) and the original dataset has a vertical root mean squared error of $0.183 \mathrm{ft}$ (5.6 centimeters). By using HECGeoRAS, a set of procedures, tools, and utilities for processing geospatial data in ArcGIS, elevation data were extracted from the DEM for 80 cross sections and subsequently were input to the HEC-RAS model. Because lidar data cannot provide ground elevations below a stream's water surface, channel cross sections were surveyed by USGS field crews during 2012 and 2014. Cross-sectional depths were measured using an echosounder at 49 locations. A differential global positioning system (DGPS) was used to derive horizontal locations and the elevation of the water surface at each surveyed cross section. Where possible, DEM-generated cross sections were made to coincide with the locations of the within-channel field-surveyed cross sections. In these cases, within-channel data were directly merged with the DEM data. For all other cross sections, the within-channel data were interpolated from the closest field-surveyed cross section in the ArcMap application of ArcGIS (Esri, 2014), using a bathymetry mesh tool that was created by Merwade and others (2008). The density of ground elevations in the mesh was determined by two variables: (1) the number of parallel longitudinal profiles that were evenly spaced across the channel and ran the length of the study reach and (2) the user-specified spacing between cross sections. Ground elevations were either extracted or interpolated from the field data at the intersections of 51 longitudinal profiles and cross sections that were spaced $200 \mathrm{ft}$ apart. The mesh elevations were subsequently added to the DEM data of the synthetic cross sections before the data were exported to HEC-RAS. Instructions for the bathymetry mesh tool are presented by Merwade (2011).

\section{Hydraulic Structures}

Many structures in and along the White River affect or have the potential to affect water-surface elevations during floods, including bridges, dams, and levees. Twelve bridges cross the White River in the study reach, including nine roadways (W. Michigan St., W. New York St., W. Washington St., Oliver Ave., Kentucky Ave., Interstate 70, W. Morris St., W. Raymond St., and S. Harding Ave.), two railroad bridges, and a pedestrian bridge (the former W. Washington St., north of the current W. Washington St. bridge). Bridge-geometry data were obtained from field surveys conducted by personnel from the USGS Indiana Water Science Center, the Indianapolis Department of Public Works (Tracey Humphrey, written commun., 2012 and 2013), the Indiana Department of Transportation (Ron Raney, written commun., 2012), and from a HEC-2 model (U.S. Army Corps of Engineers, 1991) that was used for the 2005 FIS (Federal Emergency Management Agency, 2005). Most of the bridges in the study reach have been partially reconstructed or altered since the HEC- 2 model was developed for the FIS, and one bridge that was included in the HEC-2 model has been removed. The most recent data available was used for each bridge. Two broad-crested concrete and rock low-head dams are present in the study reach, one of which forms the downstream extent of the study reach. The cross-sectional elevations of these dams were surveyed by USGS personnel. Levees are present along much of the study reach; those at the northern end of the study reach in downtown Indianapolis were constructed by the U.S. Army Corps of Engineers (Federal Emergency Management Agency, 2005) and are included in the National Levee Database (U.S. Army Corps of Engineers, 2014). The city of Indianapolis maintains levees along the southern part of the study reach, and in addition, some roadway embankments act as levees during high flow (National Weather Service, 2014a). To indicate the uncertainty of levee effectiveness in the extents of flood inundation, especially in areas where roadway embankments act as levees, two simulations were run in HEC-RAS: (1) a simulation in which all known levees, and areas that appeared to be levees in the lidar data, were included as fully functioning levees in the HEC-RAS model, and (2) a simulation in which these areas were not simulated as 'levees' in the HEC-RAS model; rather, where appropriate to do so, the landward side of the levees was simulated as ineffective flow area up to the elevation of the top of the levee.

\section{Energy-Loss Factors}

Hydraulic analyses require the estimation of energy losses that result from frictional resistance exerted by a channel on flow. These energy losses are quantified by the Manning's roughness coefficient (" $n$ " value). Initial (precalibration) $n$ values were selected on the basis of the FIS hydraulic model (Federal Emergency Management Agency, 2005) and field conditions. An $n$ value of 0.030 was selected for the wide, low-gradient main channel. The overbank areas adjacent to the main channel have a mix of trees and shrubs and park space; initial $n$ values of 0.050 and 0.030 were selected. Commercial, industrial, and densely populated residential areas occur on both banks of the White River, but are typically outside of areas that can carry effective flow.

As part of the calibration process, the initial $n$ values were adjusted until the differences between simulated and observed water-surface elevations at the three streamgages in the study reach were minimized. The final $n$ values ranged from 0.029 to 0.032 for the main channel and 0.030 to 0.051 for the overbank areas modeled in this analysis. High $n$ values, $0.06-0.07$, were used to simulate energy losses at the two dams in the reach.

\section{Hydraulic Model}

The HEC-RAS analysis for this study was done by using the steady-state flow computation option. Steady-state flow data consisted of flow regime, boundary conditions, and peak flows that produced water-surface elevations at the streamgages' cross sections that approximated target watersurface elevations. These target elevations coincided with even 
1 -ft increments of stage, referenced to the local gage datum of the 03353000 streamgage. Subcritical (tranquil) flow regime was assumed for the simulations. The peak flows that were used in the model were discussed in the section, "Hydrologic Data."

The HEC-RAS model was calibrated to the current stage-discharge relations at the White River streamgages at Raymond Street (station number 03353000), Michigan Street (station number 03352953), and at Stout Generating Station (station number 03353611). Normal depth was used to define the downstream boundary condition; an initial water-surface slope was estimated from lidar data (Greater Indianapolis Area Aerial Lidar Survey, 2010; Woolpert, Inc., 2011). Model calibration was accomplished by adjusting Manning's $n$ values and the downstream water-surface slope (final value 0.00023 ) until the results of the hydraulic computations closely agreed with the observed water-surface elevations for given flows. Differences between observed and simulated water-surface elevations for the 11 simulated flows were equal to or less than $0.12 \mathrm{ft}$ at all three streamgages (tables 4,5 , and 6). The results demonstrate that the model is capable of simulating accurate water levels over a wide range of flows in the basin.

Table 4. Calibration of model to target water-surface elevations at U.S. Geological Survey streamgage on White River at Michigan Street at Indianapolis, Indiana (station number 03352953).

[ft, feet; NAVD 88, North American Vertical Datum of 1988]

\begin{tabular}{cccc}
\hline $\begin{array}{c}\text { Stage of } \\
\text { water-surface } \\
\text { profile (ft) }\end{array}$ & $\begin{array}{c}\text { Target } \\
\text { water-surface elevation } \\
\text { (ft, NAVD 88) }\end{array}$ & $\begin{array}{c}\text { Modeled } \\
\text { water-surface elevation } \\
\text { (ft, NAVD 88) }\end{array}$ & $\begin{array}{c}\text { Difference } \\
\text { in elevation } \\
\text { (ft) }\end{array}$ \\
\hline 10 & 680.71 & 680.62 & -0.09 \\
11 & 681.39 & 681.35 & -0.04 \\
12 & 682.08 & 682.08 & 0.00 \\
13 & 682.78 & 682.80 & 0.02 \\
14 & 683.51 & 683.55 & 0.04 \\
15 & 684.22 & 684.28 & 0.06 \\
16 & 684.96 & 685.02 & 0.06 \\
17 & 685.71 & 685.75 & 0.04 \\
18 & 686.47 & 686.50 & 0.03 \\
19 & 687.22 & 687.22 & 0.00 \\
20 & 687.97 & 687.93 & -0.04 \\
\hline
\end{tabular}

Table 5. Calibration of model to target water-surface elevations at U.S. Geological Survey streamgage on White River at Indianapolis, Indiana (station number 03353000).

[ft, feet; NAVD 88, North American Vertical Datum of 1988]

\begin{tabular}{cccc}
\hline $\begin{array}{c}\text { Stage of } \\
\text { water-surface } \\
\text { profile (ft) }\end{array}$ & $\begin{array}{c}\text { Target } \\
\text { water-surface elevation } \\
\text { (ft, NAVD 88) }\end{array}$ & $\begin{array}{c}\text { Modeled } \\
\text { water-surface elevation } \\
\text { (ft, NAVD 88) }\end{array}$ & $\begin{array}{c}\text { Difference } \\
\text { in elevation } \\
\text { (ft) }\end{array}$ \\
\hline 10 & 671.76 & 671.66 & -0.10 \\
11 & 672.76 & 672.72 & -0.04 \\
12 & 673.76 & 673.78 & 0.02 \\
13 & 674.76 & 674.82 & 0.06 \\
14 & 675.76 & 675.84 & 0.08 \\
15 & 676.76 & 676.85 & 0.09 \\
16 & 677.76 & 677.86 & 0.10 \\
17 & 678.76 & 678.88 & 0.12 \\
18 & 679.76 & 679.88 & 0.12 \\
19 & 680.76 & 680.84 & 0.08 \\
20 & 681.76 & 681.86 & 0.10 \\
\hline
\end{tabular}


Flood-Inundation Maps for the White River at Indianapolis, Indiana, 2014

Table 6. Calibration of model to target water-surface elevations at U.S. Geological Survey streamgage on White River at Stout Generating Station at Indianapolis, Indiana (station number 03353611).

[ft, feet; NAVD 88, North American Vertical Datum of 1988]

\begin{tabular}{cccc}
\hline $\begin{array}{c}\text { Stage of } \\
\text { water-surface } \\
\text { profile (ft) }\end{array}$ & $\begin{array}{c}\text { Target } \\
\text { water-surface elevation } \\
\text { (ft, NAVD 88) }\end{array}$ & $\begin{array}{c}\text { Modeled } \\
\text { water-surface elevation } \\
\text { (ft, NAVD 88) }\end{array}$ & $\begin{array}{c}\text { Difference } \\
\text { in elevation } \\
\text { (ft) }\end{array}$ \\
\hline 10 & 670.34 & 670.40 & 0.06 \\
11 & 671.17 & 671.19 & 0.02 \\
12 & 671.98 & 671.98 & 0.00 \\
13 & 672.78 & 672.76 & -0.02 \\
14 & 673.58 & 673.56 & -0.02 \\
15 & 674.35 & 674.33 & -0.02 \\
16 & 675.14 & 675.09 & -0.05 \\
17 & 675.92 & 675.90 & -0.02 \\
18 & 676.71 & 676.64 & -0.07 \\
19 & 677.47 & 677.35 & -0.12 \\
20 & 678.23 & 678.19 & -0.04 \\
\hline
\end{tabular}

\section{Development of Water-Surface Profiles}

The calibrated hydraulic model was used to generate water-surface profiles for a total of 11 stages at $1-\mathrm{ft}$ intervals from 10 to $20 \mathrm{ft}$ as referenced to the local datum of the White River at Indianapolis, Ind., streamgage. These stages correspond to elevations of 671.76 and $681.76 \mathrm{ft}$, NAVD 88, respectively. Discharges corresponding to the various stages were obtained from the current stage-discharge relation for the White River at Indianapolis streamgage. Discharges through the study reach were adjusted, as necessary, for tributary inflows as shown in table 3.

\section{Development of Flood-Inundation Maps}

Flood-inundation maps were created for the White River at Indianapolis, Ind., streamgage (station number 0335000), which has been designated as an NWS flood-forecast point. The maps were created in a GIS by combining the watersurface profiles and DEM data. The DEM data were derived from the same lidar data described previously in the section "Topographic and Bathymetric Data." The resulting inundation maps have an estimated vertical accuracy of $1 \mathrm{ft}$ (that is, plus or minus $0.5 \mathrm{ft}$ ). Estimated flood-inundation boundaries for each simulated profile were developed with HEC-GeoRAS software (U.S. Army Corps of Engineers, 2009), which processes simulation results exported from HEC-RAS (U.S. Army Corps of Engineers, 2010). Shapefile polygons and depth grids of the inundated areas for each profile were modified, as required, in the ArcMap application of ArcGIS (Esri, 2014) to ensure a hydraulically reasonable transition of the flood boundaries between modeled cross sections.
Any inundated areas that were detached from the main channel were examined to identify subsurface connections with the main river, such as through culverts under roadways. Where such connections existed or appeared to exist in aerial photographs, the mapped inundated areas were retained in their respective flood maps; otherwise, they were deleted. The flood-inundation areas are overlaid on high-resolution, georeferenced, aerial photographs of the study area. Bridge surfaces are displayed as inundated regardless of the actual watersurface elevation in relation to the lowest structural chord of the bridge or the bridge deck. Estimates of water depth can be obtained from the depth-grid data that are included with the presentation of the flood maps on an interactive USGS mapping application described in the following section, "FloodInundation Map Delivery." The flood map corresponding to the highest simulated water-surface profile, a stage of $20 \mathrm{ft}$, is presented in figure 2 .

\section{Flood-Inundation Map Delivery}

The current study documentation is available online at the U.S. Geological Survey Publications Warehouse (http://dx.doi. org/10.3133/sir20155051). Also, a Flood Inundation Mapping Science Web site (http://wimcloud.usgs.gov/apps/FIM/FloodInundationMapper.html) (U.S. Geological Survey, 2014c) has been established to make USGS flood-inundation study information available to the public. That site links to a mapping application that presents map libraries and provides detailed information on flood extents and depths for modeled sites. The mapping application enables the production of customized flood-inundation maps from the map library for the White River at Indianapolis, Ind. A link on this Web site connects to 


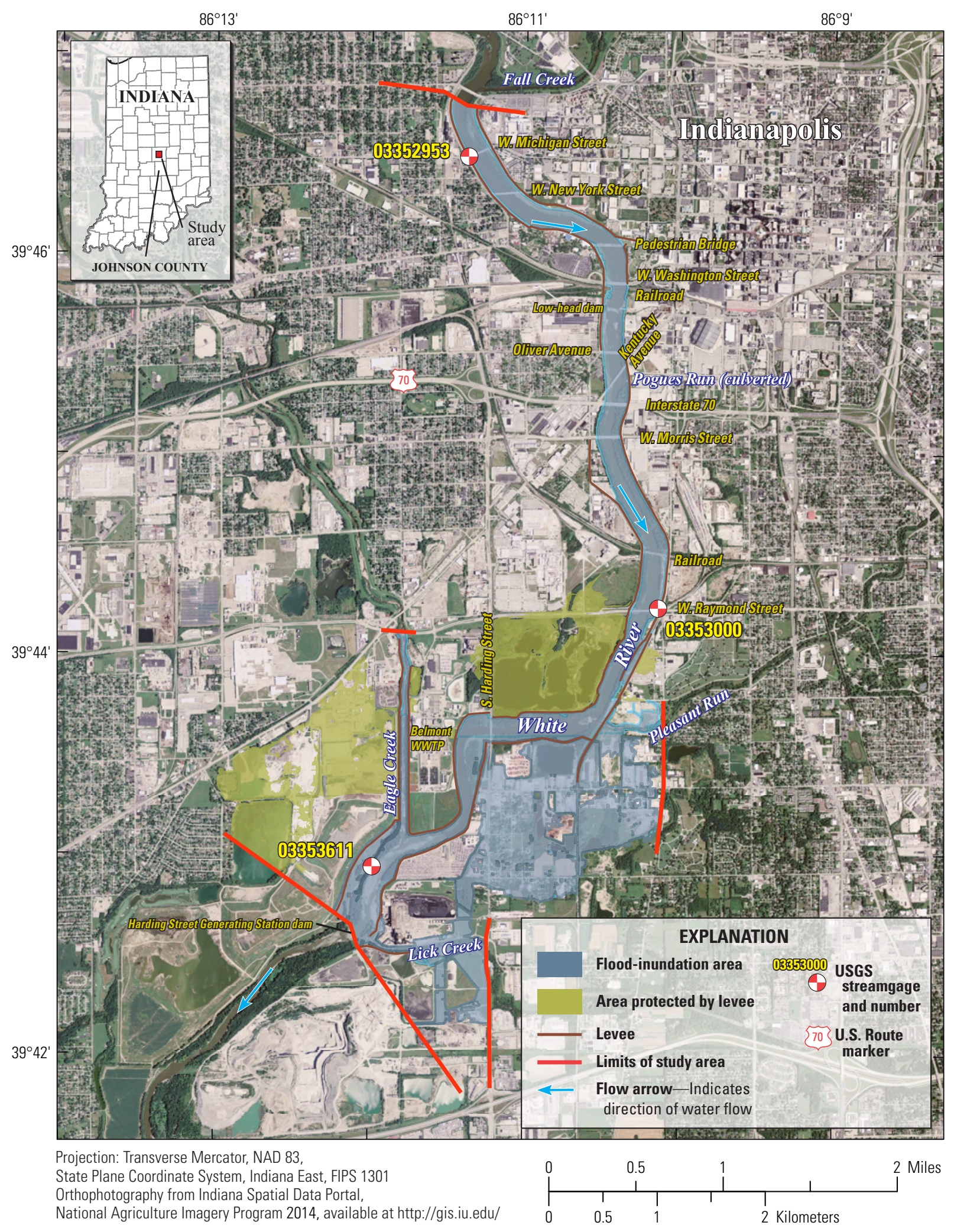

Figure 2. Flood-inundation map for the White River at Indianapolis, Indiana, corresponding to a stage of 20.00 feet at the U.S. Geological Survey (USGS) streamgage (station number 03353000). 
the USGS National Water Information System (U.S. Geological Survey, 2014a), which presents the current stage and streamflow at the USGS streamgage 03353000 to which the inundation maps are referenced. A second link connects to the NWS AHPS site (National Weather Service, 2014a) so that the user can obtain applicable information on the forecasted peak stage. The estimated flood-inundation maps are displayed in sufficient detail so that preparations for flooding and decisions for emergency response can be performed efficiently. Depending on the flood magnitude, roadways are shown as shaded (inundated and likely impassable) or not shaded (dry and passable) to facilitate emergency planning and use. Bridges are shaded - that is, shown as inundated - regardless of the flood magnitude. A shaded building should not be interpreted to mean that the structure is completely submerged; rather that bare earth surfaces in the vicinity of the building are inundated. In these instances, the water depth (as indicated in the mapping application by holding the cursor over an inundated area) near the building would be an estimate of the water level inside the structure, unless flood-proofing measures had been implemented.

\section{Disclaimer for Flood-Inundation Maps}

The flood-inundation maps should not be used for navigation, regulatory, permitting, or other legal purposes. The USGS provides these maps "as-is" for a quick reference, emergency planning tool but assumes no legal liability or responsibility resulting from the use of this information.

\section{Uncertainties and Limitations Regarding Use of Flood-Inundation Maps}

Although the flood-inundation maps represent the boundaries of inundated areas with a distinct line, some uncertainty is associated with these maps. The flood boundaries shown were estimated on the basis of water stages and streamflows at selected USGS stream gages. Water-surface elevations along the stream reaches were estimated by steady-state hydraulic modeling, assuming unobstructed flow, and using streamflows and hydrologic conditions anticipated at the USGS streamgage(s). The hydraulic model reflects the land-cover characteristics and any bridge, dam, levee, or other hydraulic structures existing as of August 2014. Unique meteorological factors (timing and distribution of precipitation) may cause actual streamflows along the modeled reach to vary from those assumed during a flood, which may lead to deviations in the water-surface elevations and inundation boundaries shown. Additional areas may be flooded due to unanticipated conditions such as changes in the streambed elevation or roughness, backwater into major tributaries along a main stem river, or backwater from localized debris or ice jams. The accuracy of the floodwater extent portrayed on these maps will vary with the accuracy of the DEM used to simulate the land surface.
If this series of flood-inundation maps will be used in conjunction with NWS river forecasts, the user should be aware of additional uncertainties that may be inherent or factored into NWS forecast procedures. The NWS uses forecast models to estimate the quantity and timing of water flowing through selected stream reaches in the United States. These forecast models (1) estimate the amount of runoff generated by precipitation and snowmelt, (2) simulate the movement of floodwater as it proceeds downstream, and (3) predict the flow and stage (and water-surface elevation) for the stream at a given location (AHPS forecast point) throughout the forecast period (every 6 hours and 3 to 5 days out in many locations). For more information on AHPS forecasts, please see: http:// water.weather.gov/ahps/pcpn_and_river_forecasting.pdf.

At least four additional sources of uncertainties are pertinent to flood inundation near the White River in Indianapolis. First, flooding due to flow in tributaries to the White River is not addressed by the inundation maps; only the flood profile in the main stem of the river is included in the hydraulic model. Areas near tributaries are modeled for inundation based on the flood profile in the White River but flow in tributaries can cause additional inundation. Second, levees line much of the modeled reach. Because the actual extent and depth of flooding in the areas behind these levees during a particular flood event are uncertain, the maximum extent of flooding if the levees did not exist is shown in the inundation maps as "areas of uncertainty due to a levee." Third, in some locations, the outlets of storm sewers might become submerged as water levels rise in the White River; flooding can then occur in areas with no apparent direct connection to the river during intense rainfall. Fourth, because Eagle Creek joins the White River within the study reach, releases from the Eagle Creek Reservoir may cause variable backwater conditions within the study reach and thereby cause actual conditions to deviate from modeled conditions.

\section{Summary}

A series of 11 digital flood-inundation maps were developed in cooperation with the Indiana Office of Community and Rural Affairs for the White River at Indianapolis, Indiana. The maps cover a reach about 6.4 miles (mi) long from 0.1 mi downstream of the confluence with Fall Creek to the Harding Street Generating Station dam. The maps were developed by using the U.S. Army Corps of Engineers' HECRAS and HEC-GeoRAS programs to compute water-surface profiles and to delineate estimated flood-inundation areas and depths of flooding for selected stream stages. The HEC-RAS hydraulic model was calibrated to the current stage-discharge relations at the U.S.Geological Survey (USGS) White River streamgages at Indianapolis (station number 03353000), at Michigan Street at Indianapolis (station number 03352953), and at Stout Generating Station at Indianapolis, 
(station number 03353611). The model was used to compute 11 water-surface profiles for flood stages at 1-foot (ft) intervals referenced to the 03353000 streamgage datum and ranging from $10 \mathrm{ft}$, or near bankfull, to $20 \mathrm{ft}$, which is the highest stage in the stage-discharge relation for the streamgage and the National Weather Service (NWS) "moderate flood stage." The simulated water-surface profiles were then combined with a geographic information system (GIS) digital-elevation model derived from light detection and ranging (lidar) data to delineate estimated flood-inundation areas as shapefile polygons and depth grids for each profile. These flood-inundation polygons were overlaid on high-resolution, georeferenced aerial photographs of the study area. The flood maps are available through a mapping application that can be accessed on the USGS Flood Inundation Mapping Science Web site (http://water.usgs.gov/osw/flood_inundation).

Interactive use of the maps on this mapping application can give users a general indication of depth of water at any point by using the mouse cursor to click within the shaded areas. These maps, in conjunction with the real-time stage data from the USGS streamgage, White River at Indianapolis, Ind. (station number 03353000), and forecasted flood stage data from the NWS Advanced Hydrologic Prediction Service will help to guide the general public in taking individual safety precautions and will provide emergency management personnel with a tool to efficiently manage emergency flood operations and postflood recovery efforts.

\section{References Cited}

Citizens Energy Group, 2014, 2013 Drinking Water Report, Indianapolis, Morgan County, and Plainfield, accessed July 29, 2014, at http://www.citizensenergygroup.com/ pdf/2013WaterReport.pdf.

City of Indianapolis, 2014, Local Flood Hazard, accessed August 4, 2014, at http://www.indy.gov/eGov/City/DCE/ Infrastructure/FloodPlain/Pages/FloodHazard.aspx.

Esri, 2014, ArcGIS, accessed August 4, 2014, at http://www. esri.com/software/arcgis/.

Federal Emergency Management Agency, 2005, Flood Insurance Study, Marion County, Indiana, all jurisdictions: Washington, D.C., 74 p., 96 pl.

Federal Emergency Management Agency, 2014, Preliminary Flood Insurance Study, Marion County, Indiana, all jurisdictions: Washington, D.C., 131 p., 190 pl.

Greater Indianapolis Area Aerial Lidar Survey, 2010, Remote sensing image: Indianapolis Metropolitan Planning Organization (IndyMPO), Indianapolis Mapping and Geographic Infrastructure System (IMAGIS), Indianapolis, Ind.
Kim, M.H., Morlock, S.E., Arihood, L.D., and Kiesler, J.L., 2011, Observed and forecast flood-inundation mapping application-A pilot study of an eleven-mile reach of the White River, Indianapolis, Indiana: U.S. Geological Survey Scientific Investigations Report 2011-5138, 63 p., 3 app.

Merwade, Venkatesh, 2011, Creating river bathymetry mesh from cross-sections: Purdue University, School of Civil Engineering, accessed March 15, 2013, at http://web.ics. purdue.edu/ vmerwade/research/bathymetry_tutorial.pdf.

Merwade, Venkatesh; Cook, Aaron; and Coonrod, Julie, 2008, GIS techniques for creating river terrain models for hydrodynamic modeling and flood inundation mapping: Environmental Modelling and Software, v. 23, nos. 10-11, p. 1300-1311.

National Weather Service, Indianapolis Weather Forecast Office, 2009, September 2003 Flood, accessed August 4, 2014, at http://www.crh.noaa.gov/ind/?n=sept03_flood.

National Weather Service, 2014a, Advanced Hydrologic Prediction Service, White River (IN) at Raymond Street in Indianapolis, accessed July 29, 2014, at http://water.weather. gov/ahps2/hydrograph.php?wfo=ind\&gage=indi3.

National Weather Service, 2014b, National Weather Service Glossary, accessed July 29, 2014, at http://w1.weather.gov/ glossary/index.php?word=action+stage.

Silver Jackets, 2013, Community Profiles-Indianapolis, Indiana, accessed August 4, 2014, at http://mrcc.isws.illinois. edu/1913Flood/communities/indianapolis.shtml.

U.S. Army Corps of Engineers, Hydrologic Engineering Center, 1991, HEC-2 Water Surface Profiles, user's manual [variously paged].

U.S. Army Corps of Engineers, Hydrologic Engineering Center, 2009, HEC-GeoRAS, GIS Tools for Support of HEC-RAS using ArcGIS, user's manual, ver. 4.2 [variously paged].

U.S. Army Corps of Engineers, Hydrologic Engineering Center, 2010, HEC-RAS River Analysis System, Hydraulic Reference Manual, ver. 4.1 [variously paged].

U.S. Army Corps of Engineers, 2014, National Levee Database, accessed July 29, 2014, at http://nld.usace.army.mil/ egis/f?p=471:1.

U.S. Census Bureau, 2010, American FactFinder, accessed July 29, 2014, at http://factfinder2.census.gov.

U.S. Geological Survey, 2013, Water-resources data for the United States, water year 2013: U.S. Geological Survey Water-Data Report WDR-US-2013, site 03353000, accessed at http://wdr.water.usgs.gov/wy2013/pdfs/03353000.2013.pdf. 
U.S. Geological Survey, 2014a, USGS 03353000 White River at Indianapolis, IN: U.S. Geological Survey, accessed

July 29, 2014, at http://waterdata.usgs.gov/in/nwis/uv?site_ no $=03353000$.

U.S. Geological Survey, 2014b, USGS surface-water data for the Nation: U.S. Geological Survey, accessed July 29, 2014, at http://waterdata.usgs.gov/nwis/sw.
U.S. Geological Survey, 2014c, USGS Flood Inundation Mapping Science: U.S. Geological Survey, accessed July 29, 2014, at http://water.usgs.gov/osw/flood_inundation.

Woolpert, Inc., 2011, Indiana Statewide Imagery and LiDAR Program, Remote sensing image: Dayton, Ohio, Woolpert Inc. 



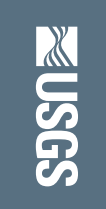

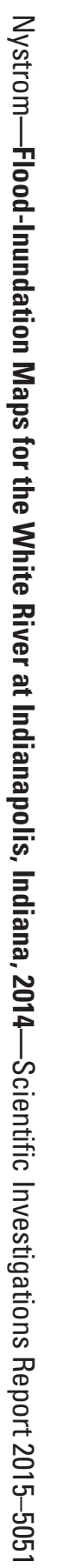

